\title{
Florida Fresh: Persimmons ${ }^{1}$
}

\section{Claudia Peñuela ${ }^{2}$}

\section{Nutrition Facts}

\section{Florida's Persimmons are:}

$\checkmark$ High in soluble fiber. Soluble fiber reduces the risk of heart disease. $\checkmark$ High in vitamin A. Vitamin A aids in normal vision, healthy skin, and protects against infections.

$\checkmark$ High in vitamin C. Vitamin C helps to heal cuts and keeps teeth and gums healthy.

$\checkmark$ High in manganese. Manganese is used as energy.

$\checkmark$ Supplier of vitamin $B_{6}$. Vitamin $B_{6}$ is involved in protein metabolism.

$\checkmark$ Supplier of potassium. Potassium helps to control blood pressure.

$\checkmark$ Naturally free of fat, and cholesterol and low in sodium.

Note: Varieties of persimmons are hachiya and fuyu.

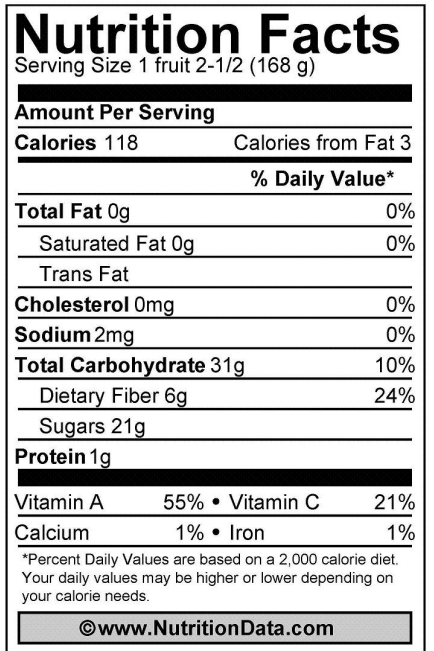

\section{Why Buy Locally?}

The U.S. Department of Agriculture (USDA) estimates that the average farmers' market produce travels about $\mathbf{5 0}$ miles to its destination, compared to $\mathbf{2 , 0 0 0}$ miles for supermarket produce.

Buy locally and get these benefits:

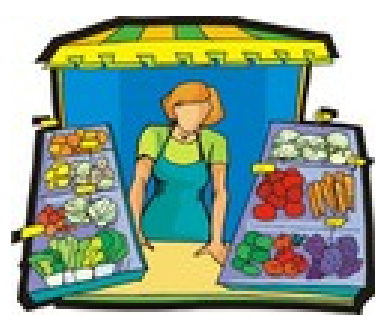

Freshness and good nutrition. Fruits and vegetables harvested in their peak have better flavor and nutritional characteristics.

Social/cultural. Helps the community to be aware of the importance of agriculture.

$>$ Environmental. Protects the natural resources such as green space, wildlife, water, air, and soil.

Economic. Promotes local labor force.

\section{Where are Florida's persimmons harvested?}

Most of Florida's persimmons are grown in Central and North Florida. However, hachiya persimmons grow best in South Florida.

1. This document is FCS8876, one of a s eries of the Department of Family, Youth and Community S ciences, Florida Cooperative Extension S ervice, Institute of Food and Agricultural Sciences, University of Florida. First published: August 2009.Visit the EDIS Web site at http://edis.ifas.ufl.edu.

2. Claudia P eñuela, nutrition a ssistant-EFNEP, D epartment of F amily, Youth and Community S ciences; Institute of Food a nd Agricultural S ciences; University of Florida; Gainesville, FL 32611. 


\section{When can you buy Florida persimmons?}

You can buy Florida persimmons from September through December. This is four months out of the year!

\begin{tabular}{|l|l|l|l|l|l|l|l|l|l|l|l|}
\hline JAN & FEB & MAR & APR & MAY & JUN & JUL & AUG & SEP & OCT & NOV & DEC \\
\hline
\end{tabular}

\section{Select}

$\checkmark$ Dark orange color hachiya persimmons.

$\checkmark$ Light orange fuyu persimmons.

Note: Since the persimmon is a very colorful fruit (yellow to red), its color is not a sign of ripeness. So, follow the next tips.

$\checkmark$ Fuyu persimmons that are firm, crisp, and tomato-shape. Fuyu persimmons are non-astringent, so they are eaten raw as a snack, or as topping for yogurt or salads.

$\checkmark$ Hachiya persimmons that are juicy, soft to the touch, and acorn-shaped. Hachiya persimmons are astringent and taste bitter, so they are used more often in baking.

$\checkmark$ Persimmons that are shiny and have a smooth skin without bruises or cracks.

$\checkmark$ Persimmons that have the stem cap attached and the leaves at the top.

Note: Buy firmer persimmons and allow them to ripen in a paper bag if you do not plan to eat immediately.

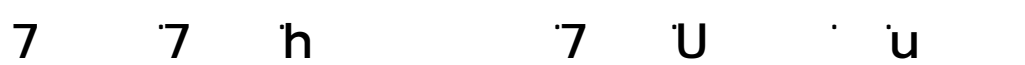

\section{Persimmons and Apple salad}

3 firm-ripe Fuyu persimmons, rinsed, stemmed, and thinly sliced lengthwise

3 sweet variety apples, rinsed, cored, and thinly sliced lengthwise

1 Tbsp walnut pieces, toasted

2 Tbsp orange juice

1 Tbsp sherry vinegar

1 Tbsp olive oil

\section{Yield: 6 Servings Time: 15 minutes}

1. In a bowl, combine orange juice, vinegar, and olive oil.

2. Add apples, persimmons, and toasted walnuts and mix to coat.

* Nutrition info per serving ( $1 / 6$ of recipe): Calories: 120 cal; Total Fat 0g; Sodium 0mg; Total Carbohydrates 25g; Fiber 4g; Protein 1g; Vit A 30\%; Vit C 20\%; Calcium 2\%; Iron 2\%* Vitamin A, Vitamin C, Calcium and Iron listed as $\%$ of daily value based on 2,000 calories

Adapted from: http://apps.nccd.cdc.gov/dnparecipe/recipesearch.aspx

\section{Persimmons Pudding}

2 cups pulp of Hachiya persimmons: they have to be soft and mushy

2 Tbsp butter

$1 / 3$ cup sugar

2 eggs

1 cup skim milk

1 cup flour

1 tsp baking soda

$1 / 2$ tsp salt

\section{Yield: 6 Servings}

1. Grease a pan and preheat oven to $350^{\circ} \mathrm{F}$.

2. Cream the butter and sugar, add the eggs and pulp, beat.

3. Add the dry ingredients alternately with milk.

4. Pour into the pan and bake 45 to 50 minutes.

Nutrition info per serving (148g): Calories: 212 cal; Total Fat 4g; Sodium 442 mg; Total Carbohydrate 39g; Fiber 3g; Protein 6g; Vit A 23\%; Vit C 7\%; Calcium 8\%; Iron 8\% 